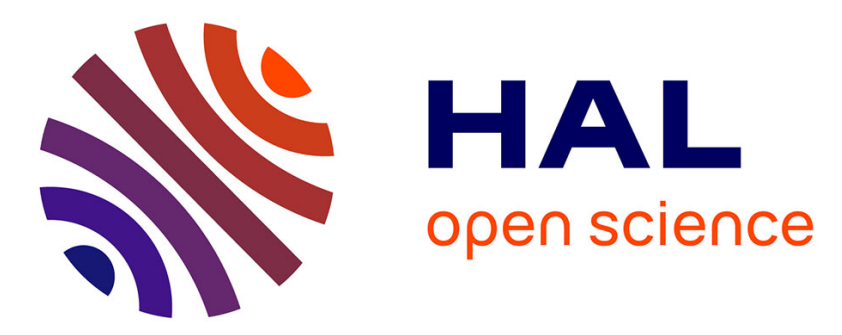

\title{
A novel conductometric sensor based on a PVC membrane containing nonactin for ammonium determination
}

B. Khadro, P. Namour, F. Bessueille, D. Leonard, N. Jaffrezic Renault

\section{- To cite this version:}

B. Khadro, P. Namour, F. Bessueille, D. Leonard, N. Jaffrezic Renault. A novel conductometric sensor based on a PVC membrane containing nonactin for ammonium determination. International Journal of Environmental Analytical Chemistry, 2009, 89 (1), p. 11 - p. 19. 10.1080/03067310802339785. hal-00508423

\section{HAL Id: hal-00508423 \\ https://hal.science/hal-00508423}

Submitted on 3 Aug 2010

HAL is a multi-disciplinary open access archive for the deposit and dissemination of scientific research documents, whether they are published or not. The documents may come from teaching and research institutions in France or abroad, or from public or private research centers.
L'archive ouverte pluridisciplinaire HAL, est destinée au dépôt et à la diffusion de documents scientifiques de niveau recherche, publiés ou non, émanant des établissements d'enseignement et de recherche français ou étrangers, des laboratoires publics ou privés. 


\title{
A novel conductometric sensor based on a PVC membrane containing nonactin for ammonium determination
}

\author{
Basma Khadro $^{\mathrm{a}}$, Philippe Namour ${ }^{\mathrm{b}}$, François Bessueille ${ }^{\mathrm{a}}$, Didier Leonard ${ }^{\mathrm{a}}$, Nicole Jaffrezic- \\ Renault $\mathrm{t}^{\mathrm{*}}$ \\ ${ }^{a}$ Université de Lyon. LSA (Laboratoire des Sciences Analytiques) UMR CNRS 5180 \\ Université Claude Bernard - Lyon, Bâtiment Raulin, 5ème étage \\ 69622 Villeurbanne Cedex, France \\ ${ }^{b}$ Cemagref of Lyon, 3 bis quai Chauveau, 69336 Lyon Cedex 09, France
}

Keywords: Conductometric sensor; Ammonium; Nonactin; Polyvinylchloride; Natural water analyses.

*Corresponding author: tel: +33472431182, fax: +33472431206

E-mail:nicole.jaffrezic@univ-lyon.fr

\begin{abstract}
This work presents a new sensor for ammonium determination based on interdigitated conductometric thin-film planar electrodes. It was fabricated by including nonactin in a plasticized PVC membrane deposited on the sensitive area of the transducer. The effects of $\mathrm{pH}$, buffer concentration, the interferences of $\mathrm{Na}^{+}, \mathrm{K}^{+}$and $\mathrm{Ca}^{2+}$ ions, the effect of ionic strength and of temperature were investigated. The linear working range and sensitivity of the biosensor were also determined. The sensitivity of the ammonium detection was around $6.25 \mu \mathrm{S} / \mu \mathrm{M} \mathrm{NH}{ }_{4}^{+}$and the detection limit was $2 \times 10^{-5} \mathrm{M}$. The biosensor exhibits the advantages of a simple fabrication procedure, good sensor-to-sensor reproducibility, wide dynamic range, and good storage stability (12 weeks).
\end{abstract}




\section{Introduction}

Over the last years, the measurement of ammonium $\left(\mathrm{NH}_{4}{ }^{+}\right)$for different purposes has become increasingly important. In environmental field, eutrophication, the excessive growth of biomass as a consequence of high nutrient inputs, leads to the perturbation of the ecological balance of a water body [1]. The growth and decay of biomass may cause oxygen depletion or hypoxia, resulting in problems such as increased fish mortality. On the other hand, ammonium is a preferred micronutrient for many plants and phytoplankton and thus makes it a key water quality parameter in studies of eutrophication [2, 3]. Even low concentrations of ammonium can adversely affect aquatic life, such as reduction in hatching success and growth rate as well as injury to gill tissue, liver and kidneys [4]. In addition, ammonium can penetrate the cell membrane under alkaline conditions. In excess, it is harmful to aquatic life by accumulating in organism and causing alteration in metabolism and body $\mathrm{pH}$ [5]. Coma and even death may occur at extremely high levels [6]. For human health, ingestion of ammonium-contaminated food may result in corrosion of mouth lining, esophagus and stomach $[7,8]$. For water disinfection process, measurements of ammonium are important because it competitively reacts with the disinfection agent hypochlorous acid to form less effective disinfectant [9, 10]. Therefore, ammonium is an essential parameter in the assessment of potable water quality and industrial process. In river water, European directives have defined the maximum allowable concentration to be in the 0.04 to $0.2 \mathrm{mg} / \mathrm{NH}_{4}{ }^{+}$range, depending on the sort of fish living in the river. So, ammonium sensors which could be placed in situ are needed to perform a direct monitoring.

Due to its importance, various methods have been developed for the estimation of ammonium concentration in different samples using different detection techniques such as spectrophotometry, chromatographic techniques [11], fluorescence [12, 13], colorimetry [14]. Some enzymatic or chemical reactions involve either consumption or production of charged species and, therefore, lead to a global change in the ionic composition of the tested sample that can be detected with conductometric biosensors. These sensors present a number of advantages (a) thin-film electrodes are suitable for miniaturization and large-scale production using inexpensive technology; (b) they do not require any reference electrode; (c) transducers are not light sensitive; (d) the driving voltage can be sufficiently low to decrease significantly the power consumption and (e) large spectrum of compounds of different nature can be determined on the basis of various reactions and mechanisms $[15,16]$. 
In this work, we develop a new conductometric ammonium biosensor by using ammonium selective PVC poly(vinylchloride) membrane containing nonactin at an interdigitated thinfilm electrode surface. Moreover, ammonium electrodes prepared by using PVC have more advantages: high stability, short response time, good reproducibility, high lifetime, easy for sensor construction. We also determined lifetime, response time, optimum working range, and other response characteristics of the sensors.

\section{Experimental}

\subsection{Reagents}

Nonactin from streptomyces griseus were provided by Sigma, diisononyl phtalate (DNP approx. 80\%) and Hexamethyldisilazane purum $\geq 98.0 \%$ (GC) were purchased from Fluka and tetrahydrofuran $(\mathrm{THF}>99 \%)$ was purchased from Sigma. $\mathrm{Ca}\left(\mathrm{NO}_{3}\right)_{2} .4 \mathrm{H}_{2} \mathrm{O}(>99.0 \%$, Fluka), ammonium, sodium and potassium chloride were obtained from Fluka and were dissolved in ultra pure water $(18 \mathrm{M} \Omega . \mathrm{cm})$. Polyvinylchloride (PVC) and EDTA ( $>99.0 \%$, Fluka) was purchased from Fluka.

\subsection{Solutions}

Stock solutions of $\mathrm{NH}_{4}{ }^{+}$were prepared in a $20 \mathrm{mM}$ phosphate buffer solution, 1.0mM EDTA, $\mathrm{pH}$ being adjusted by addition of $\mathrm{HCl}$ or $\mathrm{NaOH}$. Solutions containing other ions $\left(\mathrm{Ca}\left(\mathrm{NO}_{3}\right)_{2}\right.$, $\mathrm{NaCl}$ and $\mathrm{KCl}$ ) were obtained by serial dilution with phosphate buffer.

\subsection{Sensor design}

Conductometric transducers, consisting of two identical pairs of gold interdigitated thin film electrodes, were obtained from Research Institute of Microdevices (Kiev, Ukraine). Two pairs of $\mathrm{Au}$ interdigitated electrodes $(150 \mathrm{~nm}$ thick) were made using the lift-off process on a ceramic substrate $(5 \times 30 \mathrm{~mm})$. Both the digit width and interdigital distance were $20 \mu \mathrm{m}$, and their length was about $1.0 \mathrm{~mm}$. As a result, the "sensitive" area of each electrode was about 1 $\mathrm{mm}^{2}[17]$.

The lift-off process used is the following one: 
The deposition is thermo vacuum sputtering of chromium $(5 \mathrm{~nm})$ and gold $(150 \mathrm{~nm})$ on ceramic substrates.

1. Photoresist is positive with thickness of $3 \mu \mathrm{m}$ with resolution of 400 lines $/ \mathrm{mm}$.After deposition by centrifugation the photoresist is drying under air, after is heated at $60{ }^{\circ} \mathrm{C}$, after is heated at $120^{\circ} \mathrm{C}$.

2. Photomask is positive, photolithography is contact optical positive. After exposition under $\mathrm{UV}$ is development in $0.5 \% \mathrm{KOH}$ and washing-off the photoresist from exposed area.

3. Wet etching of gold in nitro/hydrochloric acid, etching of chromium in special solution.

4. Washing-off photoresist by dimethylformamide, washing by distilled water and drying.

\subsection{Measurements}

With each pair of interdigitated electrodes, (sensor) conductometric measurements were performed by applying a small-amplitude alternating voltage $10 \mathrm{mV}$ peak-to-peak of $100 \mathrm{kHz}$ generated by a low-frequency wave-form generator (Schlumberger type 4431). The differential output signal between working and reference sensor was recorded using a Stanford Research Systems lock-in amplifier SR510 and the responses of the sensor were recorded as a function of substrate concentration. At frequencies higher than $10 \mathrm{kHz}$, the impedance of diffusion can be neglected and the total impedance of the system consisted mainly of the resistance of the electrolyte solution in series with, the double layer capacitance and the polarization resistance in parallel to each other [17]. The in phase signal from both sensors were compared only in terms of the resistance contribution and its variation was followed.

Measurements were carried out in daylight at room temperature in a $5 \mathrm{ml}$ glass cell filled with $1.0 \mathrm{mM}$ phosphate buffer $\mathrm{pH} 7.5$ strongly agitated. After the stabilization of the signal, the substrate was added to the phosphate buffer.

\subsection{Preparation of the electrode}

For the preparation of the membrane, a typical procedure was applied using PVC and DNP (7mg PVC and 3mg of DNP ) in a ratio of 7:3 (w/w), dissolved in $1 \mathrm{~mL}$ THF, with $3 \%$ of nonactin as ionophore ; $\mathrm{NH}_{4} \mathrm{Cl}$ was added to the resulting solution in order to obtain identical concentrations of $\mathrm{NH}_{4}{ }^{+}$and nonactin. For the reference sensor the membrane composition was PVC and DNP (7mg PVC and 3mg of DNP) in a ratio of 7:3 (w/w) diluted in $1 \mathrm{~mL}$ THF. 
Before deposition of the PVC membranes, a surface treatment was performed; the electrode surface was treated with HMDS (hexamethyldisilazane) vapor for $20 \mathrm{~min}$, in order to functionalize surface sites (hydroxyl groups). Moreover, the hydrophobic methyl groups at the surface insured a good adhesion of the PVC membrane. Then, the plasticized membranes were formed by depositing $0.2 \mu 1$ with a micro syringe of each of the previous solutions on the sensitive area of the sensor and the solvent was evaporated under nitrogen flow. The sensor was then dried at room temperature for 30 minutes. The electrodes were stored at $4^{\circ} \mathrm{C}$ in $20 \mathrm{mM}$ phosphate buffer ( $\mathrm{pH} 7.5)$ containing 1.0mM EDTA.

\section{Results and discussion}

\subsection{Effect of buffer concentration}

To examine the effect of buffer concentration on the response of the conductometric sensor, the slopes of the ammonium sensor were measured at different buffer concentrations varying from 0.25 to $20 \mathrm{mM}$. The responses for the ammonium sensor for different buffer concentration are presented in Figure 1. The sensitivity of the sensor was very low at buffer concentration higher than $1.0 \mathrm{mM}$. Buffer concentration lower than $0.25 \mathrm{mM}$ was not investigated due to poor buffering capacity of the solution. Thus, optimum buffer concentration $1.0 \mathrm{mM}$ was then used for further studies.

\subsection{Effect of pH}

The influence of $\mathrm{pH}$ on the response of the ammonium sensor was studied. The effect of $\mathrm{pH}$ on the sensor response was determined in $1.0 \mathrm{mM}$ phosphate buffer at different $\mathrm{pH}$ from 5 to 12, Figure 2. The sensor sensitivity is higher and stable between $\mathrm{pH} 7$ and 8 . We then use a buffer solution at $\mathrm{pH} 7.5$ throughout the experiments to obtain the highest sensitivity.

\subsection{The sensitivity and selectivity of the ammonium conductometric sensor}

After optimization of the working conditions of the sensor in $1.0 \mathrm{mM}$ phosphate buffer, $\mathrm{pH} 7.5$ we obtained a calibration curve as presented in Figure 3. The sensor response depends on $\mathrm{NH}_{4}^{+}$concentration between $4 \times 10^{-4}$ and $35 \times 10^{-4} \mathrm{M}$ with a slope $6.25 \mu \mathrm{S} / \mu \mathrm{M}$ and $r^{2}=0.99$. 
The detection limit in about $2 \times 10^{-5} \mathrm{M} \mathrm{NH}_{4}{ }^{+}$, calculated from the lower measurable variation of conductivity.

\subsection{The selectivity of ammonium sensor}

For the determination of ammonium in water or wastewater samples it was necessary to take into account interferences by $\mathrm{Na}^{+}, \mathrm{K}^{+}$and $\mathrm{Ca}^{2+}$ ions abundantly present in such samples. The selectivity has been determined by fixing concentration of the interfering ions $(0.1 \mathrm{mM})$ diluted in $1.0 \mathrm{mM}$ phosphate buffer, $\mathrm{pH} 7.5$ with varying concentrations of $\mathrm{NH}_{4}{ }^{+}$, the results are presented in Figure 4. The definition of the selectivity coefficient was extrapolated to our conductometric ammonium sensor. The value of selectivity coefficient is around 1 for the three ions. Nevertheless, it appears in Figure 4 that $\mathrm{K}^{+}$ions showed the higher interfering effect compared to that of $\mathrm{Na}^{+}$and $\mathrm{Ca}^{2+}$. The strong interference of potassium was probably because of the similar size between both ions, it was found that this antibiotic exhibits only a slight preference for $\mathrm{NH}_{4}{ }^{+}$over $\mathrm{K}^{+}$. The interference of calcium is probably due to the double positive charge [18, 19 and 20]. These results explained, the increase of $15 \%$ in conductivity in the calibration curve for natural water sample compared to the calibration curve for standard solution of ammonium, because of the presence of ions in the sample water, including $\mathrm{K}^{+}$and $\mathrm{Ca}^{2+}$ (cf. Figure 5).

\subsection{Effect of temperature}

The effect of temperature on the sensitivity of this ammonium sensor was investigated by measurements at different temperatures varying from 5 to $60^{\circ} \mathrm{C}$ as presented in Figure 6 . The sensor sensitivities remained almost constant between 20 and $40^{\circ} \mathrm{C}$ and therefore it was thought that ammonium determinations can be carried out at room temperature $\left(20-25^{\circ} \mathrm{C}\right)$ by using this sensor. It can be seen that slopes decrease when temperature is higher than $45{ }^{\circ} \mathrm{C}$, but it can be noticed that the slopes decreased when temperatures was $\left(\leq 15^{\circ} \mathrm{C}\right)$, which was very important for its use on site (change of water temperature according to the season).

\subsection{Reproducibility}


The sensor was tested for its reproducibility by plotting the calibration curves for five different concentrations of $\mathrm{NH}_{4}{ }^{+}\left(2,4,6,8\right.$ and $\left.10 \times 10^{-4} \mathrm{M}\right)$ in $1.0 \mathrm{mM}$ phosphate buffer, $\mathrm{pH}$ 7.5 and repeated measurements five times for each concentration within 1 day with the same sensor (cf. Figure 7). The variation coefficient for the sensor (C.V \%) was calculated as $2.5 \%$. The acceptable linear regression was obtained in both cases in the measurement range.

\subsection{Storage stability}

Long-term storage stability is one of the key factors of a sensor performance. The variation of the sensitivity of the sensor as a function of storage time, the sensor being stored in $20 \mathrm{mM}$ phosphate buffer ( $\mathrm{pH} \mathrm{7.5)}$ at $4^{\circ} \mathrm{C}$, was presented in Figure 8. During a first period an increase of the sensitivity was observed due to the membrane conditioning. Then the sensitivity of the sensor remained stable for more than 12 weeks. After 12 weeks, a sudden decrease of the sensitivity occurs due to deterioration of the polymeric membrane.

\section{Conclusion}

In this paper a new sensor for ammonium determination based on the interdigitated conductometric thin-film planar electrodes, was fabricated by including nonactin in a plasticized PVC membrane deposited on the sensitive area of the transducer. Ammonium conductometric sensor prepared by using PVC membrane had more advantages: high stability, short time of stabilization of the signal $(5 \mathrm{~min})$, good reproducibility $2.5 \%$, high lifetime 12 weeks, easy for sensor construction. The linear working range and sensitivity of the sensor were also determined. The sensitivity of the ammonium detection was around $6.25 \mu \mathrm{S} / \mu \mathrm{M} \mathrm{NH}_{4}{ }^{+}$and the detection limit $2 \times 10^{-5} \mathrm{M}$, and linear range from 4 to $35 \times 10^{-4} \mathrm{M}$ in $1.0 \mathrm{mM}$ phosphate buffer, $\mathrm{pH} 7.5$, this sensitivity remaining constant between 20 to $40^{\circ} \mathrm{C}$. Furthermore, we investigated whether this sensor can be used for the determination of ammonium in natural water or wastewater samples.

\section{Acknowledgements}

This work was financially supported by CEMAGREF of Lyon. 


\section{References}

[1] P.Balslev, A.Lynggaard-Jensen and C.Nickelsen, Water Sci. Tech. 33, 183 (1996).

[2] A.Liikanen and P.J.Martikainen, Chemosphere. 52, 1287 (2003).

[3] P.Vaithiyanathan and C.J.Richardson, Sci. Total Environ. 205, 81(1997).

[4] U.S. Environmental Protection Agency, Quality Criteria for Water, EPA Publication 440/5-86-001, U.S. Gov. Prin. Office, Washington, DC, (1987).

[5] D.P.Simpson and D.J.Sherrard, J. Clin. Invest. 48, 1088 (1969).

[6] An introduction to Marine Biogeochemistry, S.M.Libes, Wiley, New York, (1992).

[7] National Research Council (NRC), Subcommittee on Ammonia, University Park Press, Baltimore, (1979).

[8] V.Felipo and R.F.Butterworth, Prog. Neurobiol. 67, 259 (2002).

[9] Ammonia: WRc Instrument Handbooks, S.Rusell, WRc, Swindon, UK, (1994).

[10] O.Köster and F.Jüttner, J. Microbiol. Methods. 37, 65 (1999).

[11] O.S.Wolfbeis and H.Li, Biosensors Bioelectron. 8, 161 (1993).

[12] M.Tabata, T.Murachi, J.Endo and M.Totani, J. Chromatogr. 597, 435 (1992).

[13] D.Timothy, Rhines and A. Arnold, Anal. Chim. Acta. 227, 387 (1989).

[14] E.Kandeler and H.Gerber, Biol. Fertil. Soils. 6, 68 (1988).

[15] R.S. Mikkelsen and G.A. Rechnitz, Anal. Chem. 61, 1737(1989).

[16] C.Chouteau, S.V.Dzyadevych., C.Durrieu, and J.Chovelon, Biosensors Bioelectron, 21, $273(2005)$.

[17] N.Jaffrezic-Renault and S.V.Dzyadevych, Sensors 8, 2569 (2008).

[18] A.Senillou, N.Jaffrezic-Renault, C.Martelet and F.Griffe, Mater. Sci. Eng, 6, 59 (1998).

[19] A.Gonzalez-Bellavista, J.Macanas, M.Munoz and E.Fabregas, Anal. Chim. Acta. 577, 85 (2006).

[20] W.Wroblewski, M. Chudy, A. Dybko and Z. Brzozka, Anal. Chim. Acta. 401, 105 (1999). 


\section{Figure captions}

Figure 1. Dependence of sensor response on phosphate buffer concentration. Measurements were conducted with $10^{-3} \mathrm{M}$ of $\mathrm{NH}_{4}^{+}$in phosphate buffer $\mathrm{pH} 7.5$.

Figure 2. Dependence of sensor response on $\mathrm{pH}$. Measurements were conducted with $10^{-3} \mathrm{M}$ of $\mathrm{NH}_{4}{ }^{+}$in $1.0 \mathrm{mM}$ phosphate buffer.

Figure 3. Dependence of sensor response $(\mu \mathrm{S})$ on $\mathrm{NH}_{4}{ }^{+}$concentration. Measurements were conducted in $1.0 \mathrm{mM}$ phosphate buffer, $\mathrm{pH} 7.5$.

Figure 4. Calibration curves of the ammonium sensors in presence of $0.1 \mathrm{mM}$ of interfering cations $\mathrm{Na}^{+}, \mathrm{K}^{+}$and $\mathrm{Ca}^{2+}$. Measurements were conducted in $1.0 \mathrm{mM}$ phosphate buffer, $\mathrm{pH}$ 7.5.

Figure 5. Comparison of the calibration curve of sensor response for the standard ammonium solution to the calibration curve for natural water samples, with different concentrations of $\mathrm{NH}_{4}{ }^{+}$. Measurements were conducted in $1.0 \mathrm{mM}$ phosphate buffer, $\mathrm{pH}$ 7.5.

Figure 6. Dependence of sensor response on temperature. Measurements were conducted with $10^{-3} \mathrm{M}$ of $\mathrm{NH}_{4}^{+}$in $1.0 \mathrm{mM}$ phosphate buffer, $\mathrm{pH} 7.5$.

Figure 7. Calibration curve of the sensor response for increasing $\mathrm{NH}_{4}{ }^{+}$concentration in natural water (study of the response conductivity). Measurements were conducted in $1.0 \mathrm{mM}$ phosphate buffer, $\mathrm{pH} 7.5$.

Figure 8 . Study of the sensor stability. Measurements were conducted in $1.0 \mathrm{mM}$ phosphate buffer, $\mathrm{pH} 7.5$ for $10^{-3} \mathrm{M} \mathrm{NH}_{4}{ }^{+}$concentration. 


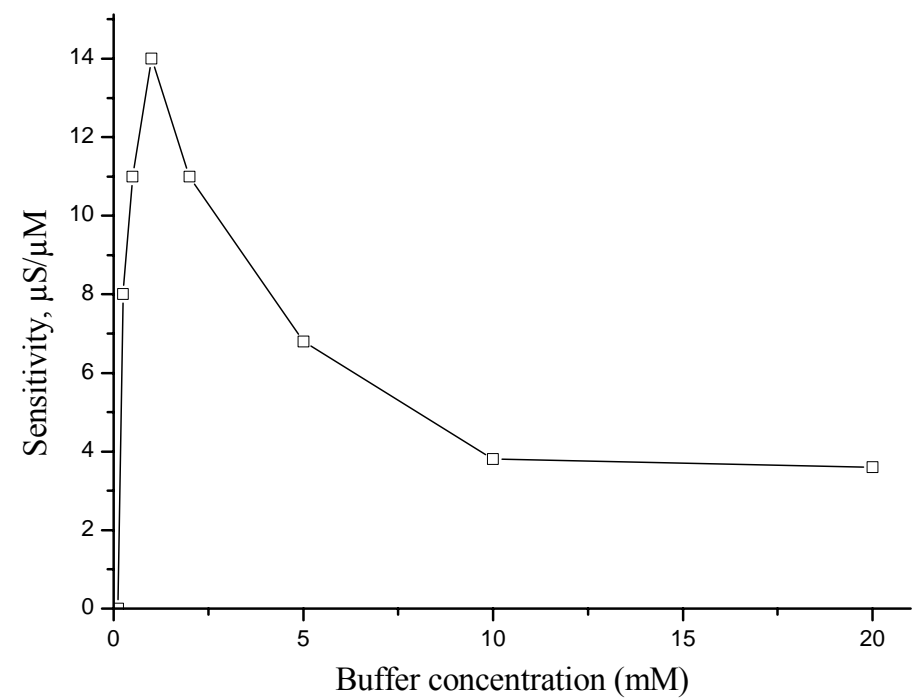

Figure 1

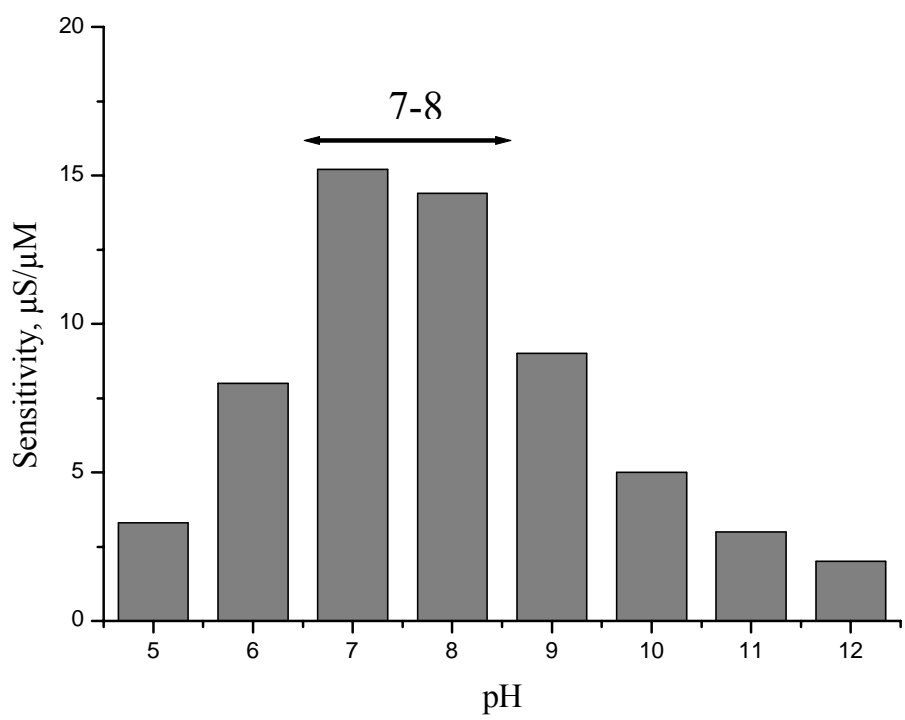

Figure 2 


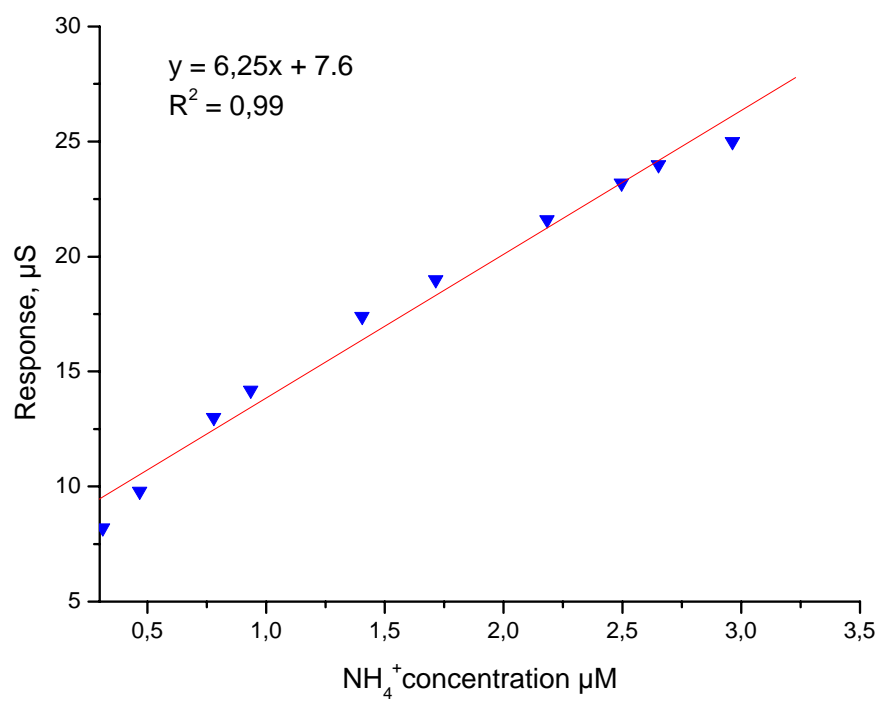

Figure 3

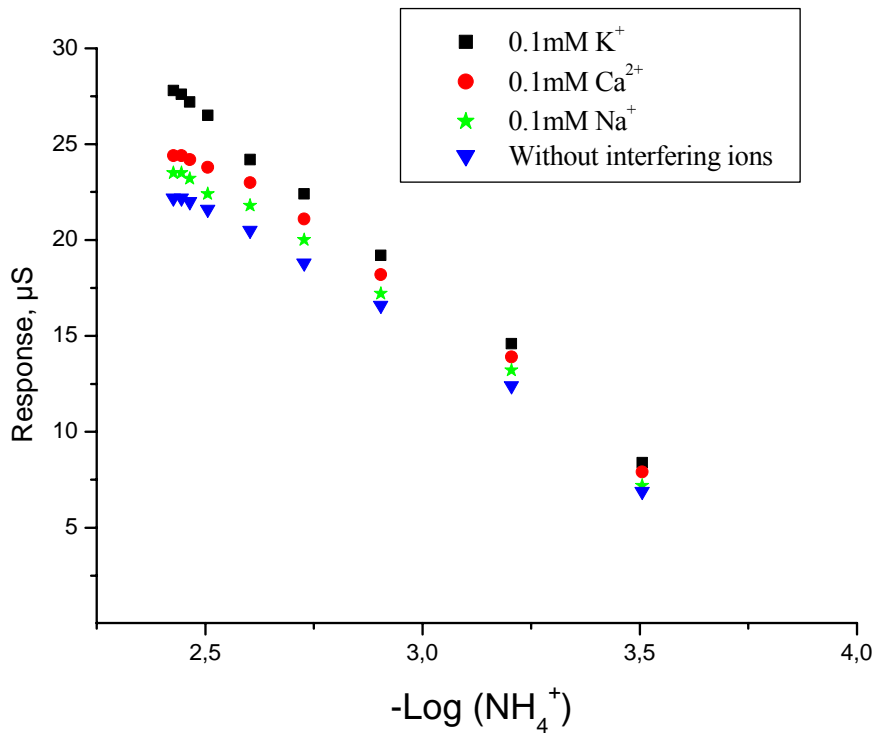

Figure 4 


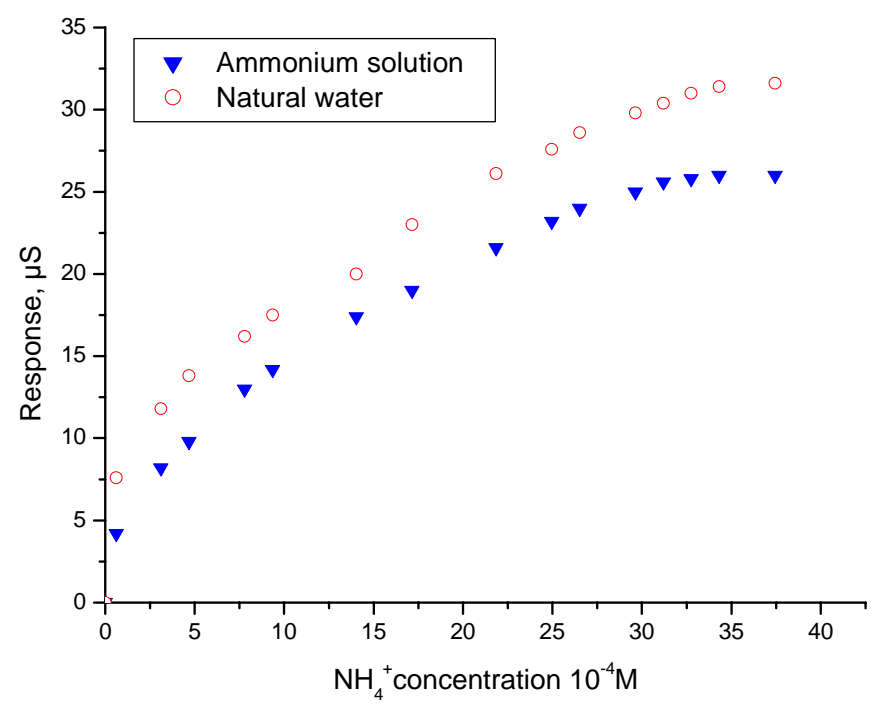

Figure 5

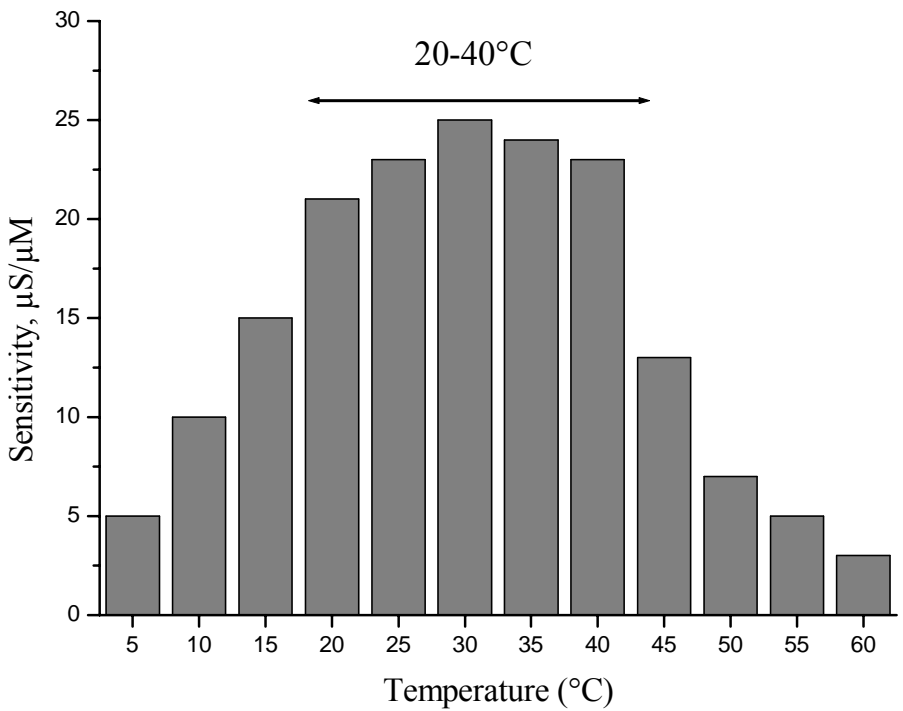

Figure 6 


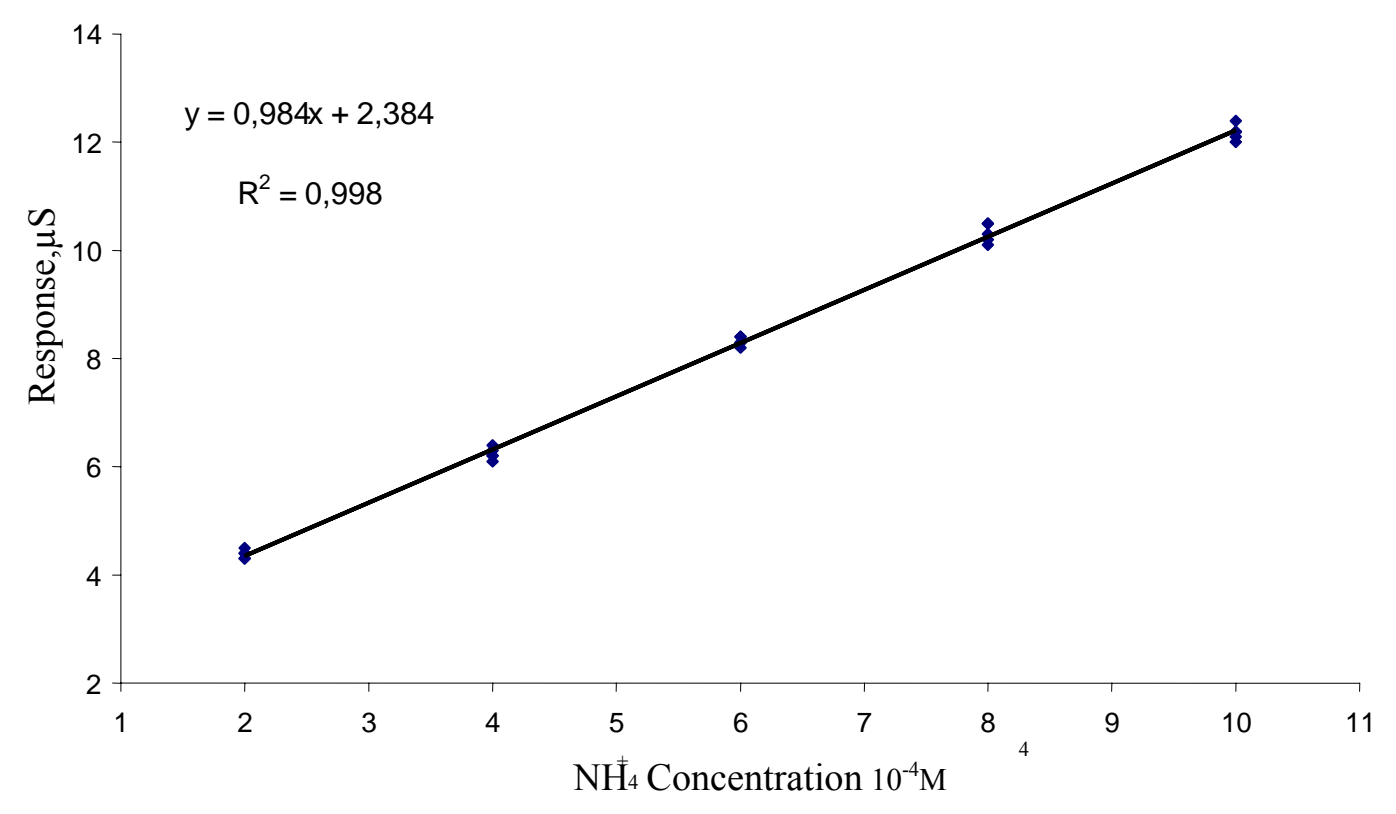

Figure 7

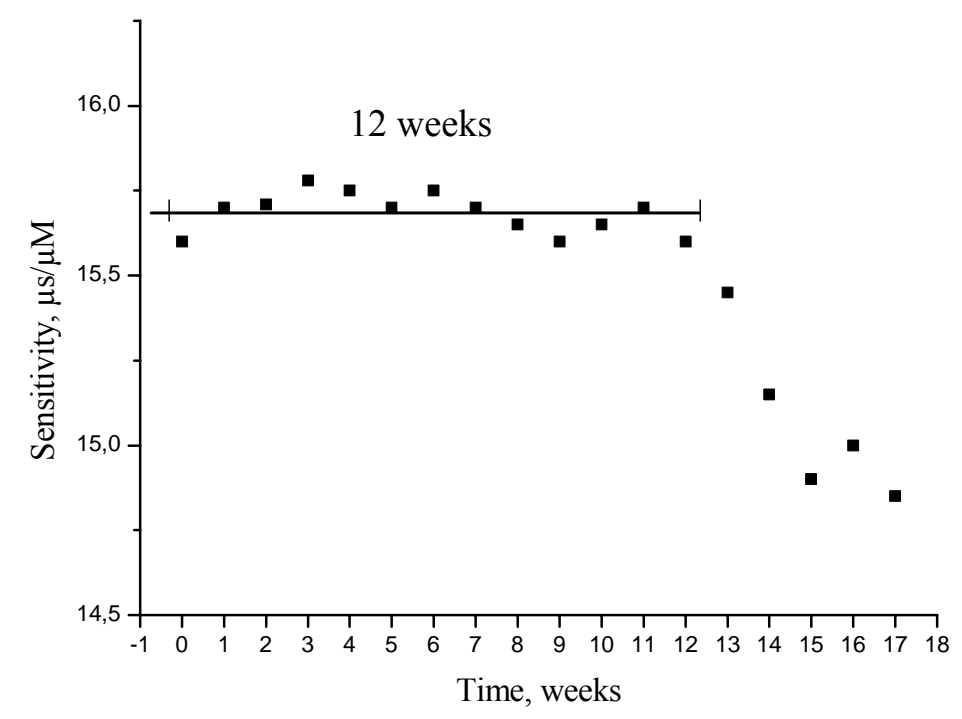

Figure 8 